\title{
KEPEMIMPINAN DIREKTUR BERPENGARUH PADA PENINGKATAN KREATIFITAS TENAGA PENDIDIK
}

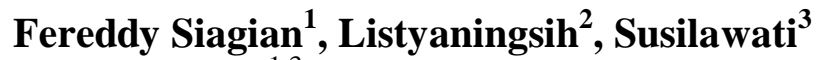 \\ Akademi Maritim Cirebon ${ }^{1,3}$, Universitas Nahdlatul Ulama Cirebon ${ }^{2}$ \\ fredy_siagian81@yahoo.com ${ }^{1}$
}

\begin{abstract}
ABSTRAK
Penelitian ini bertujuan untuk mengetahui apakah kepemimpinan direktur mempunyai pengaruh positif terhadap peningkatan kreatifitas tenaga pendidik di Akademi Maritim Cirebon. Metode penelitian yang dilakukan dalam penelitian ini adalah dengan metode kuantitatif untuk mengolah data-data yang diperoleh dari lokasi penelitian, merupakan data yang berbentuk angka atau data kuantitatif yang diangkat. Sampel yang digunakan berjumlah 266 responden yang terdiri dari semua pegawai yang bekerja dalam lingkungan AMC Cirebon dan juga mahasiswa/wi yang sedang menempuh pembelajaran di AMC Cirebon yang diambil dengan teknik non probability sampling yaitu dengan metode jenis purposive sampling, karena dalam menentukan sampel pada penelitian ini ada pertimbangan kriteria tertentu. Analisis yang digunakan dalam penelitian ini adalah uji validitas, uji reliabilitas, regresi linier sederhana, uji hipotesis dengan uji regresi secara parsial (uji t). Analisis menggunakan regresi linier sederhana didapatkan hasil $\mathrm{Y}=17,057+0,463 \mathrm{X}$ dapat diketahui bahwa persamaan regresi menunjukan suatu pengaruh yang positif dari variabel kepemimpinan terhadap peningkatan kreatifitas tenaga pendidik. Hasil uji t memiliki nilai probabilitas sig $=0,000$ lebih kecil dari nilai probabilitas 0,05 atau nilai 0,05 >0,000 (maka Ho ditolak dan Ha diterima artinya koefisien regresi adalah siginifikan. Simpulan bahwa kepemimpinan direktur $(\mathrm{X})$ memiliki pengaruh cukup signifikan terhadap peningkatan kreatifitas tenaga pendidik (Y).
\end{abstract}

Kata Kunci : Kepemimpinan Direktur, Peningkatan Kreatifitas Tenaga Pendidik.

\section{ABSTRACT}

This study aims to determine whether the director's leadership has a positive effect on increasing the creativity of educators at the Cirebon Maritime Academy. The research method used in this research is quantitative methods to process the data obtained from the research location, which is data in the form of numbers or quantitative data that is raised. The sample used amounted to 266 respondents consisting of all employees who work within the AMC Cirebon and also students who are studying at AMC Cirebon taken with a non-probability sampling technique, namely the method of purposive sampling, because in determining the sample in this study certain criteria are considered. The analysis used in this research is validity test, reliability test, simple linear regression, hypothesis test with partial regression test ( $t$ test). Analysis using simple linear regression results 
$Y=17.057+0.463 X$ can be seen that the regression equation shows an influence which is positive from the leadership variable to increase the creativity of educators. The results of the t test have a probability value of sig $=0.000$ which is smaller than a probability value of 0.05 or a value of 0.050 .000 (then Ho is rejected and Ha is accepted, meaning that the regression coefficient is significant. The conclusion is that the leadership of the director $(X)$ has a significant effect on increasing creativity of educators $(Y)$.

Keywords: Director's Leadership, Improving the Creativity of Educators.

\section{PENDAHULUAN}

Akademi Maritim Cirebon (AMC) berada di bawah 2 kementerian yaitu Kementerian Pendidikan dan Kebudayaan (Kemendikbud) dan Kementerian Perhubungan (Kemenhub). Dimana setiap Kementerian memiliki regulasi / aturan masing-masing terkait sistem pendidikan. Dan masing-masing kementerian mengharapkan agar Pendidikan harus berkualitas dalam menghadapi Masyarakat Ekonomi Asean (MEA). Untuk itu, diharapkan Direktur sebagai pemimpin harus mampu menggerakkan atau mempengaruhi stakeholder agar AMC dapat dapat memenuhi visi yang ditetapkan yaitu: Terwujudnya Perguruan Tinggi Kemaritiman yang Berkualitas dan Kompetetif yang bertaraf Internasional pada Tahun 2021.

Ada beberapa hal yang sangat menentukan kemajuan dalam pengelolaan lembaga pendidikan seperti perguruan tinggi. Unsur-unsur lembaga pendidikan tersebut meliputi unsur pemimpin, pendidik, tenaga kependidikan, peserta didik dan sarana prasarana lembaga pendidikan. Pengelolaan lembaga pendidikan sangat membutuhkan kepemimpinan yang kuat dan dengan beragam kapasitas kepemimpinan dari seorang pemimpin yang handal. Lembaga pendidikan juga membutuhkan tenaga pendidik (dosen) yang profesional dengan beragam kompetensi dan mampu menggunakan ilmu kependidikan secara profesional dan proporsional pula. Namun bagian yang tidak kalah pentingnya adalah sumber daya tenaga kependidikan perguruan tinggi yang bekerja melakukan tugas berhubungan dengan administrasi pendidikan. Namun, perlu dipahami bahwa walaupun sumber daya manusianya hebat dan lengkap namun perguruan tinggi tanpa mahasiswa sebagai peserta didik maka lembaga pendidikan tidak dapat berfungsi sebagaimana mestinya.

Pemimpin dalam pendidikan tingkat akademi dikenal dengan sebutan direktur yang berfungsi sebagai direksi atau pengarah serta pengelola para staf dan karyawan yang dipimpinnya. Direktur pendidikan dalam tingkat akademi juga berperan besar dalam memikirkan upaya peningkatan kreatifitas tenaga pendidik dan mendorong serta menyediakan sarana peningkatan kapasitas kerja tenaga kependidikan. Ini adalah bagian yang turut mendukung terciptanya proses pendidikan dan pembelajaran yang efektif dan efisien. Hal sedemikian akan memberikan dampak positif terhadap keberhasilan pembelajaran mahasiswa. 
Kepemimpinan yang baik akan dapat membangun sikap ataupun perilaku disiplin dari staf dan karyawan pengelola pendidikan. Selanjutnya, kondisi tersebut dapat membantu upaya peningkatan kinerja tenaga kependidikan serta kreasi tenaga pendidik guna menunjang keberhasilan pembelajaran mahasiswa.

Beberapa penelitian sebelumnya yang dimulai dengan topik pengaruh gaya kepemimpinan terhadap kinerja yang telah dilakukan oleh Purwanto et al. (2020) bahwa jenis gaya kepemimpinan transformational berpengaruh positif dan signifikan terhadap kinerja, tipe gaya kepemimpinan transactional berpengaruh negatif signifikan terhadap kinerja. Ramdan et al. (2020) meneliti dampak kepemimpinan transformational pada kinerja karyawan, dan kepemimpinan transactional tidak mempengaruhi kinerja karyawan. Asbari et al (2020) melakukan penelitian dan menyimpulkan bahwa pengaruh gaya kepemimpinan transformational terhadap kinerja. Gaya kepemimpinan transactional tidak mempengaruhi kinerja. Santoso et a (2019) melakukan penelitian dan menyimpulkan bahwa jenis kepemimpinan transformational negatif dan tidak signifikan mempengaruhi kinerja kepemimpinan transactional karyawan sementara tidak ada pengaruh yang signifikan terhadap kinerja karyawan. Sihite. et al (2020) melakukan penelitian dan menyimpulkan bahwa jenis kepemimpinan transformational memiliki pengaruh signifikan terhadap kepuasan kerja, jenis kepemimpinan transformational tidak memiliki pengaruh signifikan terhadap kinerja karyawan, budaya organisasi tidak memiliki dampak signifikan terhadap kinerja karyawan, dan kepuasan kerja tidak berpengaruh signifikan terhadap kinerja karyawan. Untuk meningkatkan kinerja karyawan dapat dilakukan dengan meningkatkan kepuasan kerja jika kepuasan kerja meningkat, kinerja karyawan juga akan meningkat.

Primahendra et al (2020) juga telah meneliti kepemimpinan dan hasil penelitian menunjukkan bahwa jenis kepemimpinan transformational dan model transactional memiliki efek yang kuat dan positif pada kinerja organisasi setelah mengendalikan dampak kepemimpinan transactional. Kusumaningsih et al (2020) dalam penelitian sebelumnya menyatakan bahwa pengaruh faktor-faktor organisasional dari desain pekerjaan terhadap peningkatan kinerja staf terbukti signifikan dengan aspek motivasi motivasi kerja, penelitian ini juga menemukan hubungan praktis tidak langsung antara budaya organisasi dan variabel intervening dari motivasi kerja.Melalui upaya peningkatan kreatifitas tenaga pendidik, terutama dalam seluruh kompetensinya akan serta merta membuat mereka mampu meramu dan menyusun tahapan pembelajaran pada mahasiswa. Tindakan sedemikian secara otomatis akan turut serta menciptakan atmosfir pembelajaran yang sifatnya kondusif, positif dan membangun motivasi serta suasana yang baik bagi para pendidik atau pemangku kepentingan (stakeholder) pendidikan.

Namun bagian yang paling penting dalam diri seorang pemimpin adalah kemampuan dan kelihaian pemimpin untuk mengelola sarana dan prasarana yang 
tersedia serta mengelola seluruh sumber daya pendidikan yang ada. Sebab tanpa kemampuan tersebut, maka seorang direktur dalam tugas memimpin mengelola sumberdaya yang ada maka, tidak akan dapat berjalan dengan baik sebagaimana mestinya. Oleh karena itu, seorang pemimpin harus memiliki kapasitas kepemimpinan yang handal dan bermutu tinggi. Hal ini memiliki kaitan yang erat dengan strategi pemimpin dalam memotivasi tenaga pendidik menjadi pendidik berkompeten dan profesional. Asbari at el (2020) dalam penelitiannya menyatakan bahwa dengan kepemimpinan dan budaya organisasi akan sangat berpengaruh terhadap perilaku kerja karyawan dalam dunia industri. Semua hal ini diperlukan untuk mendukung tercapainya tujuan pendidikan sesuai dengan cita-cita luhur pendidikan nasional, yakni mencerdaskan kehidupan bangsa dan mengembangkan manusia seutuhnya, sesuai dengan Undang-undang Republik Indonesia No. 20 Tahun 2003 tentang Sistem Pendidikan Nasional, menunjukkan bahwa pendidik harus mampu bersaing di forum nasional maupun internasional, profesionalisme tenaga pendidikdituntut supaya dapat terus berkembang dan tetap meningkatkan kinerja dan produktifitas sesuai dengan perkembangan jaman, ilmu pengetahuan dan teknologi.

Kondisi kepemimpinan direktur, rendahnya kreatifitas tenaga pendidikdan produktifitas kerja tenaga kependidikan dalam lingkup akademi menjadi satu keperihatinan yang perlu disikapi. Kondisi ini tentu akan berdampak negatif terhadap keberhasilan pembelajaran mahasiswa. Hal ini juga pasti akan berdampak buruk bagi kondisi disiplin kerja tenaga kependidikan. Persoalan ini tentu menjadi bentuk atau hal serius yang perlu diperhatikan oleh pemimpin dalam mengatur dan mengelola lembaga pendidikan. Isu kritis sedemikian dalam konteks pendidikan akademi menjadi perhatian penting sebab berpengaruh besar terhadap semua elemen internal pengelola pendidikan.

Sehubungan dengan isu sentral yang dikemukakan, maka penulis mencoba mengidentifikasi secara khusus faktor yang sangat mempengaruhi kreatifitas tenaga pendidik di Akademi Maritim Cirebon (AMC), maka faktor tersebut adalah faktor kepemimpinan direktur dan menjadikannya sebagai variabel kajian penelitian.

\section{METODE PENELITIAN}

Prosedur penelitian adalah urutan-urutan yang dilakukan dalam penelitian sesuai dengan langkah-langkah yang umum dilakukan dalam melaksanakan penelitian. Penetapan metode penelitian merupakan salah satu faktor yang sangat penting dalam keberhasilan suatu penelitian. Kesalahan pada metode penelitian akan dapat menyebabkan kesalahan dalam pengambilan data lapangan, analisis data dan kesimpulannya. Oleh karena itu ketepatan dalam pemilihan dan penggunaan metode penelitian harus disesuaikan dengan situasi dan kondisi, biaya, waktu dan tujuan penelitian. 
Populasi adalah totalitas semua nilai yang mungkin baik hasil menghitung ataupun pengukuran, kuantitatif maupun kualitatif dari karakteristik tertentu mengenai sekumpulan obyek yang lengkap dan jenis yang ingin dipelajari sifatsifatnya. Sedangkan sampel adalah sebagian dari jumlah populasi dan karakteristik yang dimiliki oleh populasi. Dalam penelitian ini jumlah populasi adalah 950 orang yang terdiri dari pegawai dan mahasiswa/wi yang ada dalam lingkungan Akademi Maritim Cirebon. Dan sampel yang digunakan adalah 266. Teknik pengambilan sampel yang digunakan dalam penelitian ini adalah non probability sampling. Non probability sampling yaitu teknik pengambilan sampel yang tidak memberikan peluang yang sama bagi setiap unsur atau anggota populasi untuk sampling yang digunakan adalah metode jenis purposive dipilih menjadi sampel. Dengan rumus yang digunakan adalah rumus Slovin.

Teknik pengumpulan data yang digunakan dalam penelitian ini adalah dengan menggunakan kuesioner dan observasi lapangan yaitu dengan studi dokumentasi guna membangun teori. Analisa data penelitian menggunakan metode statistika. Seluruh perhitungan statistik dilakukan dengan menggunakan bantuan program SPSS versi 20. Analisa data dilakukan dengan teknik Analisa Regresi. Riduwan dan Engkos A Kuncoro mengatakan: "Regresi adalah suatu proses memperkirakan secara sistematis tentang apa yang paling mungkin terjadi dimasa yang akan datang berdasarkan informasi masa lalu dan sekarang yang dimiliki agar kesalahannya dapat diperkecil. Regresi dapat juga diartikan sebagai usaha memprediksi perubahan. Analisis Regresi yang dipakai dalam penelitian ini adalah Analisis Regresi Sederhana dilakukan dengan bantuan SPSS versi 20.

\section{HASIL PENELITIAN}

\section{Uji Validitas}

Untuk hasil uji validitas diketahui dari nilai korelasi antara skor item dengan skor total. Nilai ini kemudian dibandingkan dengan $r$ tabel. $r$ tabel dicari pada signifikasi 0,05 dengan uji 2 sisi dan jumlah data $(n)=50$, maka didapat $r$ tabel sebesar 0,279.

Tabel.1 Hasil Uji Validitas Variabel Kepemimpinan Direktur

\begin{tabular}{|c|}
\hline Pearson Correlation \\
\hline $\begin{array}{l}, 563 * *, 333 *, 471 * *, 363 * *, 457 * *, 201,356 *, 479 * *, 161,239,253,380 * * \\
, 360 *, 415 * *, 453 * *, 411 * *, 148,261,370^{*} *, 394 * *, 269,205,210,086 \\
, 032-, 048,148,082,167,258,111,088,261,159,152,357 *, 251,339 * \\
, 420 * *, 128,189,047,289 *, 335 *, 467 * *, 297 *, 359 *, 482 * *, 169,372 * *\end{array}$ \\
\hline Sig. (2-tailed) \\
\hline $\begin{array}{l}\text {,000,018,001,010,001,161,011,000,264,095,076,006,011 ,003,001 } \\
\text {,003,305,067,008,005,059,153,143,552,828,739,305,572,247,071,443 } \\
\text { 542,067,272,292,011,079,016,002,376,189,747,041,017,001,036 } \\
, 011,000,240,008\end{array}$ \\
\hline
\end{tabular}


Untuk nilai korelasi bagi item 6, 9-11, 17-18,21-35,37, 40-42 dan 49 nilai korelasi kurang dari 0,279. Maka dapat disimpulkan bahwa item-item tersebut tidak berkorealsi signifikan dengan skor total (dinyatakan tidak valid) sehingga harus dikeluarkan atau diperbaiki. Sedangkan pada item-item lainnya nilainya lebih dari 0,279 dan dapat disimpulkan bahwa butir instrumen tersebut valid. Untuk item yang tidak valid maka harus dibuang atau diperbaiki.

Tabel.2 Hasil Uji Validitas Variabel Kreatifitas Tenaga Kependidikan

\begin{tabular}{|c|c|c|c|c|c|}
\hline \multicolumn{3}{|c|}{ Pearson Correlation } & \multicolumn{3}{|l|}{, } \\
\hline $332 *$ &, $350 *$ &, $356 *$ & ,266 &, $356 *$ &, $392 * *$ \\
\hline, $431 * *$ & \multicolumn{2}{|c|}{$, 330 *, 217$} &, 193 &, $312 *$ & ,091 \\
\hline, $313 *$ &, 244 &, $312 *$ & \multicolumn{2}{|c|}{$, 313 *, 260$} &, $405 * *$ \\
\hline, $490 * *$ &, $368 * *$ & 1 & & & \\
\hline \multicolumn{6}{|c|}{ Sig. (2-tailed) } \\
\hline 019 &, 013 & ,011 &, 062 &, 011 & ,005,002 \\
\hline \multicolumn{2}{|c|}{$, 019,131,178$} &, 028 &, 530 & \multicolumn{2}{|c|}{$, 027,088,028,027$} \\
\hline ,069 &, 003 & ,000 &, 008 & & \\
\hline \multicolumn{6}{|c|}{$* *$ Correlation is significant at the 0.01 level $(2$-tailed) } \\
\hline \multicolumn{6}{|c|}{$*$ Correlation is significant at the 0.05 level (2-tailed). } \\
\hline
\end{tabular}

Untuk nilai korelasi bagi item 4, 9-10, 12,14 dan 17 nilai korelasi kurang dari 0,279. Maka dapat disimpulkan bahwa item-item tersebut tidak berkorealsi signifikan dengan skor total (dinyatakan tidak valid) sehingga harus dikeluarkan atau diperbaiki. Maka dapat disimpulkan bahwa item-item tersebut berkorealsi signifikan dengan skor total (dinyatakan valid).

\section{Uji Reliabilitas}

Pada penelitian ini, uji reliabilitas dilakukan dengan menggunakan pendekatan internal consistensy reliability yang menggunakan Cronbach Alpha untuk mengidentifikasikan seberapa baik item-item dalam kuesioner berhubungan antara satu dengan yang lainnya. Selanjutnya Priyatno (2010) mengutip Sekaran (1992), reliabilitas kurang dari 0,6 adalah kurang baik, sedangkan 0,7 dapat diterima dan di atas 0,8 adalah baik.

Tabel 3. Hasil Uji Reliabilitas

\begin{tabular}{ccc}
\hline Variabel & $\begin{array}{c}\text { Cronbach's } \\
\text { Alpha }\end{array}$ & Keterangan \\
\hline Kepemimpinan & 0.777 & Realibel \\
\hline Kreatifitas & 0.660 & Realibel \\
\hline
\end{tabular}


Dari data tabel diatas, dapat diketahui bahwa seluruh item pernyataan dari masing-masing variabel dalam penelitian ini semua menunjukan nilai yang reliabel. Hal ini dikarenakan nilai cronbach alpha dari masing-masing variabel bernilai lebih dari 0,60 .

\section{Hasil Analisis Regresi Sederhana}

Bagian ini menyajikan hasil analisis regresi penelitian. Hasil yang disajikan adalah berupa hasil analisis regresi sederhana. Penyajian hasil analisis regresi tersebut adalah sebagai berikut.

Tabel 4. Hasil Koefisien Determinasi

\begin{tabular}{ccc}
\hline Nilai R & Nilai R Square & Nilai Adjusted R Square \\
\hline $\mathbf{0 , 6 4 6}$ & $\mathbf{0 , 4 1 7}$ & $\mathbf{0 , 4 1 5}$ \\
\hline
\end{tabular}

Tabel 5. Hasil Regresi Sederhana Dan Uj t

\begin{tabular}{|c|c|c|c|}
\hline Variabel & Nilai Koefisen & Nilai Uji t & Nilai Sig \\
\hline (Constant) & 17,057 & & \\
\hline $\begin{array}{c}\text { Kepemimpinan } \\
\text { Direktur }\end{array}$ & 0,463 & 13,749 & $\mathbf{0 , 0 0 0}$ \\
\hline
\end{tabular}

Persamaan regresinya sebagai berikut: $\mathrm{Y}^{\prime}=\mathrm{a}+\mathrm{bX}, \mathrm{Y}^{\prime}=17,057+0,463 \mathrm{X}$. Arti persamaan ini adalah konstanta sebesar 17,057; artinya jika Kepemimpinan Direktur (X) nilainya adalah 0, maka Kreatifitas Tenaga Pendidik (Y) nilainya sebesar 17,057. Koefisien regresi variabel Kepemimpinan Direktur (X) sebesar 0,463; artinya jika Kepemimpinan Direktur mengalami kenaikan 1 poin, maka Kreatifitas Tenaga Pendidik (Y) akan mengalami peningkatan sebesar 0,463. Koefisien bernilai positif artinya terjadi hubungan positif antara Kepemimpinan Direktur dengan Kreatifitas Tenaga Pendidik. Semakin tinggi Kepemimpinan Direktur maka semakin meningkatkan Kreatifitas Tenaga Pendidik.

Untuk uji $\mathrm{t}$ menguji signifikasi konstanta dan variabel dependen (Kreatifitas Tenaga Pendidik (Y1). Kriteria uji koefisien regresi dari variabel Kepemimpinan Direktur terhadap Kreatifitas Tenaga Pendidik (Y). Hipotesa pertama yang diajukan dalam bentuk kalimat. Ha: Kepemimpinan Direktur (X) berpengaruh secara signifikan terhadap Kreatifitas Tenaga Pendidik (Y). Ho: Kepemimpinan Direktur (X) tidak berpengaruh secara signifikan terhadap Kreatifitas Tenaga Pendidik (Y).

Hipotesis dalam bentuk statistik: Ha : Pylx $\neq 0$ Ho : Py $1 x=0$. Terlihat bahwa nilai Coefficients Variabel memiliki nilai probabilitas sig $=0,000$ lebih kecil dari nilai probabilitas 0,05 atau nilai 0,05 > 0,000 (maka Ho ditolak dan Ha diterima artinya koefisien regresi adalah siginifikan. Nilai koefisien determinasi sebesar 0,417, berarti 41,7\% variabel Kreatifitas Tenaga Pendidik (Y) dapat dijelaskan oleh variabel Kepemimpinan Direktur. Kemudian 58,3\% variabilitas 
Kreatifitas Tenaga Pendidik (Y) diterangkan oleh variabel lain. Simpulan bahwa Kepemimpinan Direktur (X) memiliki pengaruh cukup signifikan terhadap Peningkatan Kreatifitas Tenaga Pendidik (Y) sebab berada pada interval nilai 0,40 $-0,599$ adalah cukup signifikan.

\section{PEMBAHASAN}

Setelah dilakukan penyediaan data dan menganalisis data penelitian lapangan berdasarkan angket penelitian serta memberikan makna terhadapnya. Maka,uraian berikut ini dilanjutkan kepada pembahasan hasil penelitian yang telah diberi makna. Pembahasan penelitian adalah sebagai bagian yang mengulas dan membicarakan penguaraian terhadap hasil penelitian berdasarkan hasil analisis data regresi yang dikelola dengan bantuan program SPSS. Persamaan regresi yang telah diberikan maknaakan diberikan pembahasan lanjutan. Pokokpokok yang dibahas dalam bagian pembahasan ini pun adalah didasarkan pada sejumlah hipotesis penelitian yang diajukan.

Dari hasil Coefficients Variabel memiliki nilai probabilitas sig $=0,000$ lebih kecil dari nilai probabilitas 0,05 atau nilai 0,05 > 0,000 (maka Ho ditolak dan Ha diterima artinya koefisien regresi adalah siginifikan. Nilai koefisien determinasi sebesar 0,417, berarti 41,7\% variabel kreatifitas tenaga pendidik (Y1) dapat dijelaskan oleh variabel kepemimpinan direktur. Kemudian 58,3\% variabilitas kreatifitas tenaga pendidik (Y1) diterangkan oleh variabel lain. Simpulan bahwa kepemimpinan direktur $(\mathrm{X})$ memiliki pengaruh cukup signifikan terhadap peningkatan kreatifitas tenaga pendidik (Y) sebab berada pada interval nilai $0,40-0,599$ adalah cukup signifikan.

Untuk menyelesaikan tugas atau pekerjaan, seseorang harus memiliki derajat kesediaan dan tingkat kemampuan tertentu. Kepemimpinan harus sanggup mempengaruhi orang untuk melakukan pekerjaannya. Kesediaan dan keterampilan seseorang tidaklah cukup efektif untuk mengerjakan sesuatu tanpa pemahaman yang jelas tentang apa yang akan dikerjakan dan bagaimana mengerjakannya. Hal ini memberi pengertian bahwa kinerja merujuk kepada tingkat keberhasilan dalam melaksanakan tugas serta kemampuan untuk mencapai tujuan yang telah ditetapkan. Kinerja dinyatakan baik dan sukses jika tujuan yang diinginkan dapat tercapai dengan baik.Abilitas dan motivasi adalah sebagai faktor-faktor yang berinteraksi dengan kinerja.

Pemimpin (Direktur) dan tenaga pendidik dalam kinerjanya wajib meningkatkan kompetensinya masing-masing. Meningkatkan kemampuan dalam kepemimpinan sebagai pemimpin dan kompetensinya sebagai tenaga pendidik. Tenaga pendidik harus dan wajib mengembangkan kemampuan dan memanfaatkan kemampuan profesionalnya, karena pendidikan masa datang menuntut keterampilan profesi pendidikan berkualitas tinggi. Seorang pemimpin (Direktur) dapat dianggap sebagai pemimpin yang sukses jika berdasarkan pengukuran ia mampu mempengaruhi dan mengembangkan orang-orang yang 
dipimpinnya dalam hal ini tenaga pendidik. Kepemimpinan adalah kemampuan untuk mempengaruhi perilaku orang untuk mencapai tujuan tertentu dalam situasi tertentu. Kepemimpinan selalu berkorelasi dengan kepedulian sosial yang berarti ada interaksi antara pemimpin dengan yang dipimpinnya untuk mencapai tujuan dan sasaran yang sama (Primahendra et al , 2020). Ciri-ciri yang baik dari seorang pemimpin adalah kepedulian dan peka terhadap kebutuhan orang-orang yang dipimpinnya bahwa bawahan dapat didekati dan bersedia untuk mendiskusikan impian dan harapan mereka

Tenaga pendidik yang profesional harus memenuhi beberapa kriteria, yaitu (1) mempunyai komitmen terhadap mahasiswa dan proses belajarnya; (2) menguasai secara mendalam materi kuliah yang diajarkannya serta cara mengajarnya kepada mahasiswa; (3) bertanggung jawab memantau hasil belajar mahasiswa melalui berbagai cara evaluasi; (4) mampu berpikir sistematis tentang apa yang dilakukannya dan belajar dari pengalamnnya; (5) menjadi bagian dari masyarakat ilmiah dalam lingkungan profesinya.

Kepemimpinan yang demikian menimbulkan pula kreativitas tenaga pendidik dalam pembelajaran sepenuhnya optimal. Sesuai dengan pendapat Blanchard (1986) yang menyatakan bahwa kepemimpinan merupakan proses mempengaruhi aktivitas seseorang atau sekelompok orang untuk mencapai tujuan dalam situasi tertentu. Setiap saat seseorang berusaha mempengaruhi orang lain, maka orang tersebut bisa dikatakan sebagai pemimpin dan orang yang dipengaruhi adalah pengikut. Berkaitan dengan hasil penelitian ini, karena kepemimpinan direktur belum sepenuhnya dirasakan baik oleh tenaga pendidik, berarti pula belum mampu sepenuhnya mempengaruhi aktivitas tenaga pendidik untuk mencapai tujuan pembelajaran secara optimal pula. Kreativitas tenaga pendidik tidak dapat bekermbang secara baik atas kebijakan-kebijakan direktur yang belum sepenuhnya mendukung kegiatan pembelajaran.

Berdasarkan temuan penelitian,temuan yang menggambarkan bahwa kepemimpinan direktur berpengaruh signifikan terhadap kreatifitas tenaga pendidik dalam tugasnya. Menunjukkan bahwa masih ada faktor lain yang berpengaruh terhadap kreatifitas tenaga pendidik. Walaupun direktur dalam kepemimpinannya tetap berkewajiban meningkatkan kemampuannya dalam memimpin serta mengelola staf dan lembaga yang dipimpinnya.

\section{SIMPULAN}

Kepemimpinan Direktur (X) terhadap kreatifitas tenaga pendidik (Y). Hasil Analisa data yang telah diolah dapat diketahui bahwa Kepemimpinan Direktur (X) sangat berpengaruh positif dan signifikan terhadap Kreatifitas Tenaga Pendidik di Akademi Maritim Cirebon. 


\section{DAFTAR PUSTAKA}

Primahendra, R., Agus P., Ardian S., , Sekundina W., K., Rudy, P .(2020). Pengaruh Gaya Kepemimpinan Transactional, Transformational, Authentic Dan Authoritarian Terhadap Kinerja Guru Madrasah Tsanawiyah di Kudus. Al Tanzim : Jurnal Manajemen Pendidikan Islam. 4(1), 70-80

Santoso, P., Asbari, M., \& Purwanto, A. (2019).Pengaruh Kepemimpinan dan Budaya Organisasi terhadap Perilaku Kerja Inovatif Pada Industri 4.0. JIM UPB, Jurnal Ilmiah Manajemen Universitas Putera Batam, 8(1), 7-15.

Asbari, M., Hyun, C., Wijayanti, L., Winanti, W., Fayzhall, M., Putra, F., \& Pramono, R. (2020). Hard Skills dan Soft Skills: Apa Membangun Inovasi Guru Sekolah Islam.Evaluasi, Jurnal Manajemen Pendidikan Islam, 4(1), 143-172.

Blanchard, Kenneth H. \& Hersey, P. (1986). Manajemen Perilaku Organisasi : Pendayagunaan Sumber Daya Manusia. Terjemahan Agus Dharma. Jakarta : Erlangga.

Kusumaningsih, Evy, Y., Firdaus, P., Winanti, W., Donna I., Rudy, P., Innocentius, B.(2020) Pengaruh Hard Skills, Soft Skills dan Mediasi Budaya Sekolah terhadap Kapabilitas Inovasi Guru di Jawa Barat : Studi Fenomenologi Esensi Pengalaman Peserta Didik, Jurnal Kependidikan: Jurnal Hasil Penelitian dan Kajian Kepustakaan di Bidang Pendidikan, Pengajaran dan Pembelajaran, 6(1)

Ramdan, M., Purwanto, A., Asbari, \& M., Prameswari, M. (2020). Gaya Kepemimpinan di Madrasah Aliyah: Authentic, Tansformational, Authoritarian Atau Transactional. Nidhomul Haq Jurnal Manajemen Pendidikan Islam, 5(1), 16-31. https://doi.org/10.31538/ndh.v5i1.544

Sihite, O., Sulistiadi, A., \& Utama, V. (2020). The Effects of Leadership, And Organizational Culture Career Development to Work Satisfaction Employees At Pt. South Pacific Viscose, Purwakarta West Java. Jurnal Ilmiah MEA (Manajemen, Ekonomi, \& Akuntansi), 4(1) 